\title{
Privileged Exclusion in Post-Soviet Kazakhstan: Ethnic Return Migration, Citizenship, and the Politics of (Not) Belonging
}

\section{Cynthia Ann Werner, Celia Emmelhainz \& Holly Barcus}

To cite this article: Cynthia Ann Werner, Celia Emmelhainz \& Holly Barcus (2017) Privileged Exclusion in Post-Soviet Kazakhstan: Ethnic Return Migration, Citizenship, and the Politics of (Not) Belonging, Europe-Asia Studies, 69:10, 1557-1583, DOI: 10.1080/09668136.2017.1401042

To link to this article: https://doi.org/10.1080/09668136.2017.1401042

曲 Published online: 19 Dec 2017.

Submit your article to this journal $\pi$

Џ Article views: 261

View Crossmark data $\complement$ 


\title{
Privileged Exclusion in Post-Soviet Kazakhstan: Ethnic Return Migration, Citizenship, and the Politics of (Not) Belonging
}

\author{
CYNTHIA ANN WERNER, CELIA EMMELHAINZ \& \\ HOLLY BARCUS
}

\begin{abstract}
This article explores issues of citizenship and belonging associated with post-Soviet Kazakhstan's repatriation programme. Beginning in 1991, Kazakhstan financed the resettlement of over 944,000 diasporic Kazakhs from nearly a dozen countries, including Mongolia, and encouraged repatriates to become naturalised citizens. Using the concept of 'privileged exclusion', this article argues that repatriated Kazakhs from Mongolia belong due to their knowledge of Kazakh language and traditions yet, at the same time, do not belong due to their lack of linguistic fluency in Russian, the absence of a shared Soviet experience, and limited comfort with the 'cosmopolitan' lifestyle that characterises the new elite in this post-Soviet context.
\end{abstract}

WHILE SIPPING TEA IN HER DAUGHTER'S KITCHEN IN MONGOLIA, ANARA, a woman in her late sixties, told us about her experience migrating from Mongolia to Kazakhstan. ${ }^{1}$ Anara and her husband Serik were Kazakhs born and raised in western Mongolia. Until the early 1990s, they had enjoyed a comfortable yet modest life in a predominantly Kazakh region. Yet like other professionals whose education and occupation represented Mongolia's 'middle class', Anara and Serik lost their jobs as a pharmacist and truck driver respectively when the postsocialist Mongolian government introduced neoliberal reforms in 1991. At that time, Anara and Serik's eight children were young adults with limited work prospects in Mongolia. As ethnic Kazakhs, however, they had the opportunity to participate in a repatriation programme sponsored by newly independent Kazakhstan. Despite having no prior ties to Kazakhstan,

This work was supported by the Association of American Geographers (Research Grant); National Science Foundation Research Grant, Division of Behavioral and Cognitive Sciences [grant number BCS-0752411] (Geography and Spatial Sciences), [grant number BCS-0752471] (Cultural Anthropology); Texas A\&M University Office of International Programs (International Research and Travel Grant); Texas A\&M University Melbern G. Glasscock Center for Humanities Research (Stipendiary Fellowship); Texas A\&M University Women's and Gender Studies Program (Women's Interdisciplinary Seed Grant Research Awar); Macalester College (Wallace Travel and Research Grant).

${ }^{1}$ Interview with Anara, Ulgii city, Bayan-Ulgii aimaq, Mongolia, 16 June 2009. Throughout this article, pseudonyms have been used to protect the identity of research participants. 
several of Anara and Serik's older children migrated there in the 1990s through work contracts for diasporic Kazakhs who were willing to relocate to Kazakhstan.

Beginning in 1991, the repatriation programme facilitated the migration of over 944,000 self-ascribed Kazakhs from nearly a dozen countries to newly independent Kazakhstan (Lillis 2014). Mongolian Kazakhs, amongst others, found the programme attractive because Kazakhstan covered the cost of migration and resettlement, and provided housing and employment for those enrolled in the annual quota of migrants. In 1997, the programme was revamped to make it easier for repatriates to become permanent citizens of Kazakhstan (Barcus \& Werner 2010). Through the early 2000s, Kazakhstan's economic growth outpaced Mongolia's, providing most repatriates a higher salary. By 2005, most of Anara and Serik's children had left, and so the parents decided to migrate to a rural area near the city of Kokshetau (Akmolinskaya oblast'), where they joined several sons who had already established lives as private farmers. Their eldest daughter was the only child who remained in Mongolia.

As we talked, Anara shared mixed views about her move to Kazakhstan. She was initially very happy with life in Kazakhstan, where her family no longer struggled to make ends meet, and she received a larger pension once she became a naturalised citizen. After several years, however, Anara had started to regret leaving Mongolia and giving up her Mongolian citizenship. As she explained, daily life on the farm was more difficult than expected, and her larger pension did not match the higher costs of living in Kazakhstan. Like many other Kazakh repatriates (oralman), Anara had not developed a strong sense of belonging to Kazakhstan. In contrast to official rhetoric welcoming repatriates to their 'homeland', Anara experienced chauvinism from locals because she did not speak Russian very well. She resented the fact that some Kazakhs called her 'Mongolian', rather than 'Kazakh'. Instead of finding Kazakhstan to be her homeland, she felt that her homeland was stretched across national borders. While she had kept Kazakhstani citizenship, Anara remained attached to her birth country, Mongolia, which she visited every summer for several months.

During our conversation, Anara confessed that she and Serik had considered returning to Mongolia permanently but the difficulty was that neither Mongolia nor Kazakhstan allowed individuals to be citizens of two countries at the same time. If Anara were to return, it could take years to navigate the bureaucratic hoops necessary to regain her Mongolian citizenship and, during this transition, her family could become stateless, hence unsupported by either country. Anara was sceptical of Mongolian media reports claiming that return migrants could regain Mongolian citizenship in one month. Although it was easy for Anara to leave Mongolia and acquire citizenship in Kazakhstan, her actions had come with significant political, personal and legal consequences.

From a comparative perspective, Anara's story raises important questions on the relationship between citizenship and belonging-questions that come into play for all transnational migrants (Bosniak 2006; Geschiere 2009; Greenhouse 2011; Yuval-Davis 2011). Citizenship and belonging are inextricably related, yet one does not precede or ensure the other. In the contemporary world, several million people migrate across international borders every year; in each case, government policies and public attitudes towards migrants vary by country of origin, and by category of migrant. Kazakh repatriates appear to have many advantages in a world where some migrants (and refugees) face physical dangers crossing borders and traversing perilous oceans only to face stringent requirements of entrance and citizenship in their destination country. Repatriates, or 'ethnic return migrants', are defined as diasporic peoples who migrate to an ancestral 'homeland' in which they have not lived before (Tsuda 2009). Compared to many 
transnational migrants in other settings, Anara and Serik received preferential treatment due to their ethnicity rather than their social class. Not only do Kazakh repatriates have a defined path to citizenship but, as 'ethnic return migrants', they also possess a shared heritage with the dominant ethnic group in Kazakhstan.

Shared ethnic belonging and citizenship in Kazakhstan, however, had not provided Anara (and other Mongolian Kazakhs) with a strong sense of belonging to Kazakhstan. This article therefore reverses the equation, asking how migrants can have all the privileges of citizenship, receive greater social benefits than ordinary citizens, and yet not develop a strong sense of belonging. Has a political programme initially designed to include repatriated Kazakhs been thwarted by projects and actions that have served to exclude them? If so, what political processes are at play to ensure that repatriated Kazakhs do not develop a full sense of belonging to Kazakhstan? And what do these political dynamics suggest to us about citizenship and belonging more broadly?

This article argues that the experiences of Kazakh repatriates from Mongolia are best described through the concept of 'privileged exclusion', which we define as a mixture of legal preferences and social prejudices that shape their experiences with Kazakhstan. This argument is developed in three parts. To begin with, we demonstrate that ethnic return migrants have a 'privileged' status relative to other migrants, as evidenced by an easier path to citizenship and a relatively generous package of state-sponsored social welfare benefits. Secondly, we argue that many Kazakh repatriates from Mongolia only developed a partial sense of belonging, given policies and practices that maintain boundaries between autochthonous Kazakhs and repatriated Kazakhs. Finally, we argue that, over time, the social welfare package for repatriated Kazakhs has been reduced, as migration and citizenship policies have changed in response to new national priorities, and repatriates have encountered higher levels of social exclusion. Taken together, this case study illustrates that, while Kazakhstan's oralman programme has helped the country achieve its demographic goals, the development of a full sense of national belonging for repatriates requires both legal and social forms of inclusion.

\section{Theories of transnational migration, citizenship, and belonging}

This article is situated within a broad scholarly conversation about the changing relationship between states and citizens in an increasingly globalised world. Today, the majority of the world's inhabitants are recognised as legal citizens of at least one state, though a small percent remain 'stateless'. Most people become citizens either through birth within the territory of a nation-state (jus soli), birth to a parent who is a citizen (jus sanguinis), a combination of the above, or via formal processes of naturalisation (Benhabib \& Resnik 2009). Some states permit multiple citizenships, while others, including Kazakhstan, require naturalised citizens to renounce their citizenship of origin.

Scholars have historically regarded citizenship as a contract between a person and a government, in which both sides have rights and responsibilities (Marshall 1983; Tilly 1996; Miller 2000). More recently, scholars have explored new issues of citizenship associated with transnational migration (Kymlicka 1995; Ong 1999; Mandel 2008; Benhabib \& Resnick 2009; Yuval-Davis 2011). In a globally interconnected world, people around the world have become increasingly mobile, and such mobile capital and labour creates scenarios where the 'territories, rights and duties [associated with citizenship] no longer perfectly coincide' (Ruget \& Usmanalieva 2008, p. 130). Some migrants want access to a labour market without 
aspiring to citizenship, while other migrants want to become citizens of a state that does not welcome long-term immigrants. In many settings, individuals may be excluded from citizenship, yet receive some rights as 'denizens', 'aliens', or 'permanent residents' (Bosniak 2006; Mandel 2008). For example, from the 1950s up to the mid-1970s, Germany recruited 'guest workers', including four million people of Turkish descent, to fill waged positions in the industrial sector. These guest workers have the legal right to reside in the country, and their children now have the option of acquiring German citizenship (Mandel 2008). Given such multifaceted citizenship logics, transnational migrants experience an array of situations vis-à-vis both country of origin and country of destination. For example, some migrants participate in elections in their home country, while others receive social welfare benefits as non-nationals in their host country (Ruget \& Usmanalieva 2008, p. 129).

Most nation-states, especially those in the Global North, regulate and control transnational mobility through laws on migration and citizenship that prioritise social class. In countries such as the United States and Indonesia, immigration policies follow a 'neoliberal' approach that is favourable towards those who bring in capital investments or occupy highly specialised positions, while discriminating against the poor and those in low-wage positions (Ong 1999; Sassen 1999). According to Ong (1999), these states maintain their sovereignty by regulating who can enter the territory and who gains full or partial access to the privileges of citizenship. In a small number of countries, including Israel and Germany, policymakers have used an alternative approach incorporating ethnic preferences into immigration and citizenship laws as a way to address economic, demographic, or national security issues (Joppke \& Rosenhek 2009; Tsuda 2009). Kazakhstan, as we will see below, adopted a similar approach, by giving the highest priority to migrants on the basis of their ethnic heritage. Like Germany and Israel, Kazakhstan has provided repatriates, or ethnic return migrants, with a variable array of benefits and services. The case of Germany illustrates how such policies can change under new circumstances: German policies towards the repatriation of Germans from Eastern bloc countries became more restrictive after the fall of the Soviet Union, and then began to loosen up again (Hess 2016, pp. 383-86). As we argue below, Kazakhstan's policies towards repatriates have also shifted over time.

In countries with repatriation programmes, including Kazakhstan, ethnic return migrants have a significant advantage over other categories of migrants because they are able to obtain citizenship. Although modern democratic states have laws that prevent discrimination by race, gender, or class, there are no equivalent laws that protect individuals on the basis of citizenship (Kipnis 2004). To put it simply, citizens are more likely than non-citizens to have political rights, a sense of belonging, protection from deportation and denationalisation, and access to social welfare (Ceuppens \& Geschiere 2005; Benhabib \& Resnick, 2009). In Kazakhstan, the government regards repatriated Kazakhs as a preferred group of migrants who are eligible to citizenship. In comparison, other groups of migrants, particularly wage labourers from neighbouring Central Asian countries, have very limited access to citizenship.

Although citizenship certainly provides an advantage for some migrants, citizenship policies can also create and reproduce cultural differences in ways that enable some citizens to develop a greater sense of belonging to a political entity than others. As Bosniak notes, there is a certain amount of romanticism attached to the concept of citizenship and the idea of exclusive belonging that results from citizenship (Bosniak 2006). On the one hand, postcolonial states might make concessions to groups whose religious and cultural practices were persecuted in the colonial past (Castor 2013). On the other hand, states with strong national 
ideologies often exclude minorities (including immigrant groups) from the civic, political, economic, and cultural rights granted to members of the majority culture, thus limiting their sense of belonging to the state. Even 'multicultural' states choose which culture is most reflected in the process of citizenship (Craith 2004, p. 29), affecting the extent to which both citizens and non-citizens experience belonging to a state.

Processes of racialisation affect migrants from the Global South as they encounter institutions in the Global North (Thomas \& Clarke 2013). Racial markers can have lingering effects - as with Asian-Americans who are marked as 'migrants' even after living in the United States for several generations (Lowe 1996). While 'citizenship' refers to a person's legal relationship with a state, 'belonging' denotes the extent of emotional attachment to a particular place. Given that even immigrants who share cultural and physical traits can be racialised as outsiders, as East Germans and Soviet Germans experienced in reunified Germany (Sassen 1999, p. xvi; Hess 2016), these cases clearly suggest that citizenship does not always guarantee a sense of belonging. Yuval-Davis (2011) emphasises that political processes play an active role in constructing and reproducing the boundaries of the political community. Such politics of belonging may include multicultural policies that celebrate cultural differences, assimilationist policies that integrate minorities into society, or antiimmigrant movements limiting the mobility and freedom of migrants. Criteria for belonging can vary, as Geschiere (2009) demonstrates in the case of Cameroon, where social boundaries are maintained between those who claim to be autochthonous to a territory (through historical connections to natal villages and ancestral burial sites), and more recent settlers from abroad who are Cameroonian citizens.

Building on these works, this article uses the experiences of ethnic return migrants to offer a new perspective on issues of citizenship and belonging. Ethnic return migrants are in a unique situation compared to other categories of migrants. We find that ethnic return migrants from Mongolia simultaneously belong and do not belong to Kazakhstan, and that their sense of belonging, individually and collectively, changes over time. On the one hand, ethnic return migrants such as Anara often maintain transnational identities and connections. On the other hand, ethnic return migrants' sense of belonging is influenced by continuously evolving political projects of belonging and social practices in both countries, practices that serve to maintain and create distinctions between insiders and outsiders. We argue that different social groups coexist in hierarchies of belonging, where individuals in one group might have a greater sense of belonging than individuals from another group. Moreover, it is possible for this 'belonging-ness' to shift over time in either direction, and thus shift the hierarchies of belonging.

In the case of Kazakhstan, Mongolian Kazakhs like Anara and Serik have no problems acquiring citizenship but are excluded from a full sense of belonging to Kazakhstan because their perceived 'Kazakhness' exceeds in some respects that of their contemporaries in Kazakhstan. Most Mongolian Kazakhs speak Kazakh (and Mongolian) but not Russian, and many have retained customs and traditions associated with ancient Kazakhs to a greater extent than many autochthonous Kazakhs living in Kazakhstan (Diener 2005, pp. 471-72; Post 2007; Lacaze 2010, p. 197). Rather than belonging to a different place, then, it is as if these diasporic Kazakhs appear to belong to a different time - an imagined past when Kazakhs were monolingual and retained traditions associated with a nomadic pastoral lifestyle. Although these traits might have been considered desirable by the nationalist-minded Kazakhs who 
designed the repatriation programme, they make it difficult for repatriated Kazakhs like Anara and Serik to be integrated into modern Kazakhstani society.

\section{Kazakhstan's repatriation programme in the context of neoliberalism and nation-building}

The ethnographic subjects of this article are self-ascribed Kazakhs who have migrated from Mongolia to Kazakhstan through a state-sponsored repatriation programme (Diener 2009; Shugatai 2012; Alff 2013; Post 2014; Zeveleva 2014). These 'Mongolian Kazakhs' were born and raised in Mongolia, and trace their ancestry to the Xinjiang province of China rather than the nearby Steppes of Kazakhstan (Finke 1999, pp. 109-10). ${ }^{2}$ By the end of the socialist era, 123,000 Kazakhs lived in Mongolia, with nearly $80 \%$ in the country's westernmost regions (Finke 1999, p. 112). Although Mongolian Kazakhs have a shared sense of history and kinship, they are diverse in terms of lifestyle (semi-nomadic, rural, and urban), education (from elementary to higher education), occupation, linguistic fluency (in Kazakh, Mongolian, and Russian), age and gender.

This article emerges from a larger collective research project on the transnational migration of Kazakhs from Mongolia to Kazakhstan. During six months of fieldwork between 2006 and 2009, we conducted 66 semi-structured interviews and 184 structured interviews with Kazakhs living in western Mongolia. Our interviews took place in several rural settings as well as in the cities of Ulgii and Khovd, the administrative centres of Bayan-Ulgii aimaq (district) and Khovd aimaq respectively. The use of a quota sample ensured equitable representation by gender, age and degree of urbanisation. We interviewed people from a variety of occupations, including semi-nomadic herders, traders, teachers, doctors, administrators, and seamstresses. We were interested in learning how Kazakhstan's repatriation programme influenced sending communities, and how potential migrants in Mongolia considered the decision to migrate. We started with an established definition of migration as the 'movement of a person (a migrant) between two places for a certain period of time' (Boyle et al. 2013, p. 34), and then restricted the definition for this study to include those who had moved outside of their home region (that is, Bayan-Ulgii aimaq) to another country, or another aimaq of Mongolia, for a period of at least six months. Our interview questions covered a range of topics, including respondents' views on citizenship in both countries. In each of ten field locations, we lived with Kazakh families and took field notes of our daily experiences and encounters. One of our host families was preparing to migrate to Kazakhstan, letting us directly observe how families prepare for the move. Years of previous fieldwork in Kazakhstan provided additional insights for understanding social and cultural dynamics in this setting. Although most interviews took place in Mongolia, our respondents included individuals who had previously migrated to Kazakhstan before returning permanently as well as Kazakhstani citizens who were visiting relatives during the warm summer months. In addition, we met several Mongolian Kazakhs during a short trip to Kazakhstan and visited housing projects for Kazakh repatriates. To put these interviews in context, we also collected statistical information on migration, brochures for repatriates, copies of the migration laws, and Kazakhstani newspaper articles on repatriation. The latter are particularly relevant to domestic debates about the repatriation programme in Kazakhstan.

${ }^{2}$ Mongolian Kazakhs arrived in western Mongolia from China between the 1860s and the 1940s (Finke 1999, p. 109; Diener 2009, pp. 264-65). 
Until the twentieth century, Kazakhs lived as nomadic pastoralists across the Steppes and mountains of central Eurasia, where they migrated with mixed herds of sheep, goats, camels, horses and yaks. By the late 1920s, new national borders separated Kazakh populations in the Soviet Union from nearby co-ethnics in China and Mongolia. ${ }^{3}$ For most of the twentieth century, these three states limited the movement of citizens via a household registration system that made it difficult for citizens to move within the state, as well as an external passport system that restricted foreign travel to the most loyal citizens (Pipko \& Pucciarelli 1985). Kazakhs in the Soviet Union, Mongolia and China had therefore very little contact with co-ethnics in neighbouring countries. The introduction of socialist policies in all three countries, however, led to similar trajectories of change, including the development of a more diverse economy and the expansion of a socialist welfare system. To incorporate nomads into the socialist economy, these states forcibly collectivised nomads (Olcott 1987; Khazanov 1994; Humphrey $\&$ Sneath 1999). Although the timelines for instituting these policies varied from one country to the next, a significant portion of Kazakhs in each country eventually abandoned nomadic pastoralism and settled in towns with greater access to health care, education, and consumer goods. Those who continued to raise livestock were incorporated into the socialist economy, receiving wages for their work in socialist brigades that provided the state with livestock products (Olcott 1987; Benson \& Svanberg 1998; Svanberg 1999; Finke 2003, pp. 203-5).

For most of the twentieth century, Kazakhs were not members of a nation-state that was created on the basis of Kazakh identity. ${ }^{4}$ Instead, they lived as minorities in multi-ethnic states where political power was concentrated in a dominant ethnic group. This is not to say that Kazakhs did not have a special status in each of these states. In the Soviet Union, the Kazakhs, as a minority group affiliated with a union-level republic, enjoyed privileges reserved for ethnic groups with a relatively large size and territorial concentration. ${ }^{5}$ Soviet leaders used accommodative policies to gain support from ethnic minorities and prevent the development of national or religion-based alternatives to Bolshevism (Slezkine 1996; Martin 2001; Suny 2001). The Soviet state embraced the multicultural rhetoric of 'national self-determination' and 'internationalism', using linguistics and ethnography to define administrative boundaries between ethnic groups. Soviet policies towards minorities varied depending on the size of the group and changed over time (Slezkine 1996; Suny 2001; Hirsch 2005). This process of transforming fluid groups into fixed ethnic categories was aided by census categories and maps, as well as identity documents that listed ethno-national identities (Suny 2001). Similar to the Soviet Union, China and Mongolia also emphasised the links between language, territory, and ethno-national identity. China created special administrative territories for the Kazakhs, who are one of 55 recognised ethnic minority groups. In Mongolia, where they represent the largest non-Mongol ethnic group, Kazakhs are concentrated in the country's westernmost provinces. Given the significant presence of Kazakhs, all three states created Kazakh-language schools for Kazakhs (Benson \& Svanberg 1998; Davé 2007; Portisch 2012).

${ }^{3}$ China and Mongolia contain the greatest number of Kazakhs living outside the former Soviet Union. Smaller populations can be found in Afghanistan, Iran, and Turkey.

${ }^{4}$ From 1917 to 1920 , a provisional Kazakh government known as Alash Orda was formed prior to Kazakhstan's incorporation into the Soviet Union (Kendirbaeva 1999).

${ }^{5}$ In the early 1920 s, the Kazakh steppe territory of Kazakhstan was initially incorporated into the Soviet Union, together with what is now the Kyrgyz Republic, as the Kirghiz Autonomous Soviet Socialist Republic within the Russian Soviet Federated Socialist Republic (RSFSR). In 1926, there were some changes to the borders of this administrative territory which was renamed the Kazakh Autonomous Soviet Socialist Republic. In 1936, the current borders were established and the territory was designated as a union republic: the Kazakh Soviet Socialist Republic (Svanberg 1999; Abazov 2008). 
In the Soviet Union, China, and Mongolia, policies that institutionalised distinct ethnonational identities existed in tension with policies that encouraged assimilation. As a result, some aspects of culture such as religion and marriage were targeted for social change, while other features such as food and music were showcased as markers of a distinct ethnic identity. In practice, majority groups such as the Russians, Chinese and Mongolians were privileged in economic and cultural life, while minority groups such as the Kazakhs suffered from different degrees of cultural and linguistic assimilation (Benson \& Svanberg 1998; Schatz 2000, pp. 73-4; Diener 2009). Thus, over time, policies and accommodations that factored in ethnic difference were outweighed by other practices that weakened Kazakh culture and language, especially in the Soviet Union. For example, instruction was better in Russian-language schools and knowledge of Russian so crucial for social mobility in Soviet Kazakhstan that elite Kazakhs often sent their children to Russian schools; by independence, some studies indicated that $40 \%$ of Kazakhstani Kazakhs were no longer fluent in Kazakh (Fierman 2005, p. 405; Davé 2007, pp. 52-3). In contrast, the vast majority of Kazakhs living in Mongolia remained fluent in Kazakh, given their concentration in a region where they were the dominant ethnic group (Finke 1999).

In 1991, the Kazakh Soviet Socialist Republic became the independent nation of Kazakhstan. The new government initiated several state projects in this post-Soviet 'transition'. The first task involved restructuring the socialist command-administrative economy into a neoliberal market-based economy. Beginning in the early 1990s, the state privatised stateowned enterprises, such as state farms and state-owned factories, and reduced government subsidies for housing, health care and transportation (Olcott 2002, p. 146). These changes brought high rates of inflation and unemployment, and otherwise disrupted the daily lives of Kazakhstani citizens in the early 1990s (Nazpary 2001; Junisbai 2010). The second major task was the development of a more liberalised political landscape to replace the one-party system controlled by the Communist Party and guided by Marxist-Leninist ideology. This aspect of the transition involved the creation of a new constitution, loosening of government control over the media, and political reforms that, at least on paper, allowed for free and fair elections (Luong 2002; Courtney 2012).

As with other Soviet successor states, newly independent Kazakhstan also found itself 'in the grip of hectic nation-building' after the fall of the Soviet Union (Kolstø 1998, p. 51). While 'state-building' refers to the development of political institutions such as elections and bureaucracies, 'nation-building' denotes efforts to create a national identity using emotional attachments to the state and the territory that it occupies (Reynolds 2005). At the time of independence, Kazakhstan was in a unique position as the only post-Soviet state which the titular group did not constitute a majority of the population (Kolstø 1998; Schatz 2000). Kazakhs comprised $39.3 \%$ of the population and Russians $37.5 \%$ of a state with 16.5 million residents. In addition to these two largest groups, there are dozens of other ethnic groups in Kazakhstan, including Germans, Ukrainians, Uzbeks, Tatars, Uighurs, Kurds, Belarussians, Koreans and Poles (Svanberg 1999, p. 11).

After Kazakhstan became independent, residents of Kazakhstan gained Kazakhstani citizenship, regardless of ethnicity or linguistic fluency. Post-Soviet states adapted the Soviet model of internationalism to balance an ethnic-oriented Kazakh identity with a civic-oriented Kazakhstani identity. As in the Soviet past, the Kazakhstani state continues to promote cultural diversity by emphasising 'inter-ethnic harmony', maintaining language rights for non-Kazakhs, and permitting cultural associations for ethnic minority groups (Davenel 2012). 
As one study suggests, Kazakhstan's leaders have maintained a 'strategic ambiguity' between civic and ethno-nationalist tendencies as part of a 'careful balancing act' (Ó Beacháin \& Kevlihan 2013). This argument is bolstered by studies that find that most Kazakhs perceive that they have a great deal in common with Russians (Faranda \& Nolle 2011) and many non-Kazakh citizens have developed a strong attachment to the Kazakhstani nation (Spehr \& Kassenova 2012).

One of the factors that led Kazakhstan to maintain this strategic balancing act between civic and ethnic forms of nationalism relates to the social diversity of the Kazakhs themselves. On the one hand, Kazakhs are divided along sub-ethnic 'clan' identities that permeate everyday life and politics (Esenova 2002; Schatz 2004). On the other hand, scholars often portray a population divided into two groups, alternatively referred to as 'nationalists' and 'cosmopolitans' (Surucu 2002), 'nativists' and 'assimilados' (Kuzio 2002), or 'nationalist Kazakhs' and 'Russophone Kazakhs' (Kolstø 1998). These broad divides correlate with a cultural division between self-ascribed progressive, modern, secular, and urban Kazakhs, and those who seek to revive cultural traditions, celebrate Kazakh historical figures, and restore Kazakh language use (Surucu 2002). Such binary divides, while instructive for understanding the diversity of the Kazakh population, are at best seen as two abstract positions in a complex and changing demographic landscape where multiple aspects of identity overlap. There are certainly individual Kazakhs who are not accurately represented by these binary labels because they might identify as Kazakh-speaking cosmopolitans who are equally proud of their Kazakh identity and their global acumen.

Although post-Soviet Kazakhstan has been careful to promote inter-ethnic harmony, the Kazakhs have been elevated to a privileged status, as evidenced by the selection of new national symbols, holidays, and heroes. The government did not have to start from scratch in creating Anderson's (1983) notion of an 'imagined political community' amongst Kazakhs. Throughout the Soviet period, ethno-national identities were regularly reinforced by Soviet institutions, such as an internal passport system that designated an individual's ethno-national identity and administrative districts that linked language, territory and ethnicity (Kolstø 1998; Fierman 2005).

Post-Soviet nation-building has essentially reversed the Soviet hierarchy of ethnic groups ('internationalism with a Russian face') with a post-Soviet 'internationalism with a Kazakh face' (Schatz 2000). Throughout the former Soviet space, nation-building processes address ethnic-based grievances from the Soviet 'colonial' past (Kuzio 2002; Schatz 2000). Post-Soviet nation-building in Kazakhstan is moulded around four key issues: history, demography, culture, and language. A nationalist rewriting of history reframes pre-Soviet Russian-Kazakh relations, and problematises the first two decades of Soviet rule as a period when approximately 2.5 million Kazakhs fled to China (and elsewhere) or died as a result of collectivisation, famine, and repression (Kolstø 1998; Schatz 2000, p. 75; Davé 2004). From a nationalist perspective, these issues justify a concern about Russian concentrations in the northern part of Kazakhstan, as well as the fear of an influx of neighbouring population with Uzbek or Chinese backgrounds (Peyrouse 2007; Kuşçu 2008, pp. 92-5). In addition to these historical and demographic issues, Kazakhstan has also tried to reverse linguistic and cultural 'Russification' by establishing Kazakh as the 'state language' and Russian as the 'language of inter-ethnic communication': by increasing the number of Kazakh-language schools (Fierman 2005), supporting the use of Kazakh in workplaces and in the media (Peyrouse 2007), and requiring Kazakh language proficiency for government workers (Aksholakova \& Ismailova 2013). 
Kazakhstan's ethnic repatriation programme emerged in this post-Soviet context, addressing all four key issues of the nation-building project. By encouraging diasporic Kazakhs to 'return' to a new country now imagined as the 'homeland' of all Kazakhs, the programme would shift the ethnic balance in Kazakhstan to give Kazakhs a majority (Kuşçu 2008; Diener 2009). As with the 'Law of Return' granting all Jews the right to immigrate to Israel and German repatriation of ethnic Germans from Eastern bloc countries (Joppke \& Rosenhek 2009), Kazakhstan's oralman programme also aimed to redress historical grievances. From the outset, diasporic Kazakhs were portrayed as descendants of ethnic refugees forced to leave the homeland due to Soviet 'acts of mass political repression, unlawful requisition, forced collectivization, and other human acts' (Diener 2009, p. 264). In addition to increasing the number of Kazakhs in the country, the programme indirectly revives Kazakh language and culture by adding Kazakh populations, such as those from Mongolia and China, who retained Kazakh language use and cultural traditions to a greater extent than Kazakhstani Kazakhs.

\section{Creating a privileged category of migrants: the underpinnings of inclusion}

The simultaneous introduction of neoliberal reforms and an ethnic repatriation programme in post-Soviet Kazakhstan, combined with high mobility in and out of the country, offers a fascinating context for examining issues of citizenship and belonging. Beginning in the early 1990s, Kazakhstan introduced neoliberal reforms that significantly reduced social benefits for ordinary citizens. Rather than using class-based preferences for migration in line with a 'neoliberal' approach (Ong 1999), Kazakhstan introduced a migration programme that targeted diasporic Kazakhs, regardless of social class or occupation, and provided this category of migrants with special benefits that other citizens did not receive. The repatriation policy is based on the assumption that repatriates are deserving of property, jobs and social welfare benefits because of their ethnic identity as Kazakhs. This is not to say that there was not an economic need for repatriates in Kazakhstan's new economy. Many repatriates found employment, especially in the agricultural and construction sectors, and thus contributed to the national economy, especially in regions that had been depopulated by the exodus of Russians and Germans (Genina 2015, p. 52). ${ }^{6}$

Since 1992, nearly one million diasporic Kazakhs have participated in the repatriation programme, including more than 640,000 Kazakhs who migrated from other former Soviet republics to Kazakhstan and over 110,000 Kazakhs who migrated from Mongolia (the second greatest country of origin after Uzbekistan). ${ }^{7}$ The combined influx of migrants represents approximately $6 \%$ of Kazakhstan's population at the time of writing. The repatriation initiative, based on the same primordial interpretation of ethnic identity that was promulgated by Soviet nationality policy, was the focal point of early migration and citizenship laws, and continues to be a linchpin of Kazakhstan's nation-building project. Strongly endorsed at its inception in 1992 by the newly formed World Association of Kazakhs, one of the programme's key objectives was to unite all Kazakhs under the same territorial umbrella. In

${ }^{6}$ Approximately three quarters of Kazakhstan's Russian population and one third of Kazakhstan's German population have remained in the country (Olcott 2002, pp. 80-4).

${ }^{7}$ See Lillis (2014) for the total number of repatriates by 2014, and the UNHCR Report for a breakdown of repatriates by country through 2011 ('Special Report on the Situation Concerning the Rights of Oralmans, Stateless Persons and Refugees in the Republic of Kazakhstan', United Nations High Commission on Refugees Report (Astana, UNHCR Kazakhstan, 2012)). 
other words, the programme was designed to be inclusive; it was based on the assumption that Kazakhs everywhere shared patrilineal kin ties, and therefore possessed common cultural characteristics.

Shortly before Kazakhstan's independence, diasporic Kazakhs gained the opportunity to apply for five-year employment contracts to work in the Kazakh SSR (Finke 1999, p. 115). There was no corresponding opportunity for other ethnic groups. Kazakhstan's 1992 Law on Migration expanded this programme and set an annual quota for Kazakh repatriates (Barcus \& Werner 2010). ${ }^{8}$ Varying from 500 to 20,000 households per year, the quota limited the number of households that could receive government assistance. Non-quota ethnic migrants could still apply for a smaller range of benefits, even during the two years of temporary suspension of the programme (2012-2014), when no new migrants were admitted within the quota (Barcus \& Werner 2010; Oka 2013; Lillis 2014). ${ }^{9}$

In the 1990s, ethnic return migrants within the quota were eligible to receive numerous benefits, including transportation to Kazakhstan, housing, a resettlement stipend, several head of livestock, job training and free health care. ${ }^{10}$ Combined with the administrative cost of facilitating the programme, these benefits represented a considerable financial challenge for the Kazakhstani government. The programme, a key component of the state's nationbuilding project, was introduced while the economy was in turmoil and the government was slashing subsidies for existing citizens as part of its neoliberal reform project. In the early 1990s, demographics were so important that Kazakh leaders chose to prioritise this nationbuilding project, even though the social welfare benefits provided to ethnic return migrants for housing and education were similar to the benefits that existing Kazakhstani citizens had lost as a result of neoliberal reforms (Zeveleva 2014).

Kazakhstan's repatriation programme was established at the same time that Mongolia was also introducing radical economic reforms that brought about high inflation, massive unemployment, and trade disruptions. Kazakhs in the remote western provinces of Mongolia were hit particularly hard by these changes. The Mongolian Kazakhs interviewed while researching this article remember the early 1990s as a period of hunger and desperation, but also a time of new opportunities. As Amantai, an older male herder, recalled:

When the market economy started, peoples' lives were difficult. There was no money. We didn't have opportunities to buy flour and tea and other things. All things were privatised. That hard period continued ... [but] then people started to do business, and the price for livestock skins and other products increased. People's lives have improved over the last few years. Now we have enough goods in our life. Some of us study, others herd livestock, and people can now move to Kazakhstan or to the aimaq [regional] centre. So, I think lives are getting better. ${ }^{11}$

Mongolian Kazakhs developed a variety of coping strategies in response to these post-socialist economic changes. One of the more common strategies was to engage in cross-border trade,

\footnotetext{
'Status of Oralmans in Kazakhstan: An Overview', United Nations Development Programme Report (Almaty, UNDP Kazakhstan, 2008).

9'Kazakhs Resume Helping Oralman', centralasia online, available at: http://centralasiaonline.com/en_GB/ articles/caii/newsbriefs/2013/08/29/newsbrief-11, accessed 20 January 2015.

${ }^{10}$ 'Status of Oralmans in Kazakhstan: An Overview', United Nations Development Programme Report (Almaty, UNDP Kazakhstan, 2008).

${ }^{11}$ Interview with Amantai, Bayannuur som, Bayan-Olgii aimaq, Mongolia, 13 July 2009.
} 
taking advantage of western Mongolia's strategic location as a transit point between China and Russia (Lacaze 2010). Two other interviewees, Damira and Nurbek, for example, remember how they began to shuttle food products across the border between Mongolia and Russia in the early 1990s after the national border became more open. This married couple started out by purchasing inexpensive Chinese products such as packaged noodles that other merchants had brought to Mongolia, and then reselling them at a higher price in a Russian border town. They would then return to Mongolia with food staples, which they then sold in the Mongolian marketplace. Over time, they developed this into a larger business, becoming one of the leading regional distributors for key commodities. ${ }^{12}$

While some Mongolian Kazakhs, like Damira and Nurbek, chose to make the most of new opportunities in Mongolia, others opted to migrate to Kazakhstan. So many Mongolian Kazakhs took part in the repatriation programme that the majority of the Kazakhs interviewed in Mongolia mentioned close relatives who had left for Kazakhstan in the early 1990s. For example, Saule shared a vivid memory of her relatives loading their household belongings on large Soviet Kamaz trucks as they set off to new lives in Kazakhstan. ${ }^{13}$ Like other women divided by marriage, she stayed behind with her husband and his kin, while her birth parents, aunts, uncles, brothers and cousins all set off together for Kazakhstan (Werner \& Barcus 2015).

Kazakhstan's repatriation programme had great appeal amongst diasporic Kazakhs living in countries where neoliberal reforms were disrupting daily lives, as was indeed the case of Mongolia. The benefits for Kazakh repatriates were attractive even though Kazakhstan's posttransition economy was experiencing economic chaos (Nazpary 2001). For example, a middleaged woman named Karlygash told about her experience migrating from western Mongolia to Kazakhstan in 1993 on a five-year work contract. She and her husband decided to move to Kazakhstan with their six children, because it was nearly impossible to find employment in Mongolia, and her siblings had already succeeded in obtaining jobs in Kazakhstan. She remembers how it took a month to get their documents organised, but then the government of Kazakhstan facilitated the move by covering their moving expenses and transportation logistics. The move provided Karlygash and her family with economic security. Upon arrival in Kazakhstan, Karlygash and her husband were given jobs taking care of livestock on a state farm in Zhezkazgan province. ${ }^{14}$

Karlygash's story, however, also illustrates that things on the ground have not always worked out exactly as promised by the government. Although the government also promised her family a place to live, it took over six months before they were finally able to move out of temporary housing in unused office space. Studies based on ethnographic fieldwork in Kazakhstan provide further evidence that there have been various problems with the local implementation of the repatriation programme. As Diener (2009, p. 230) and Genina (2015, pp. 55-8) point out, repatriates were provided with jobs, which were however not always matched with their skills and experience. For example, some of the earliest Mongolian Kazakh repatriates were well-educated elites, including medical doctors and teachers, who were given jobs on agricultural collectives. As illustrated by Genina (2015, pp. 170-71), local officials

\footnotetext{
${ }^{12}$ Interviews with Damira and Nurbek, Ulgii city, Mongolia, 4 June 2008.

${ }^{13}$ Interview with Saule, Sagsai som, Bayan-Ulgii aimaq, Mongolia, 4 July 2006.

${ }^{14}$ Interview with Karlygash, Ulaankhus som, Bayan-Ulgii aimaq, Mongolia, 11 June 2008.
} 
developed their own methods for allocating quota benefits in a similar way. In some cases, officials base their selection of priority applicants on need while, in other regions, officials are more likely to favour applicants who pay a bribe. Repatriates have also had to learn how to navigate their way through a maze of different bureaucratic processes in order to be registered as a repatriate, receive a residency permit, and obtain a state identification number (SIK number) (Genina 2015, p. 176).

During the past 25 years, Kazakhstan adjusted its repatriation policies as its political needs changed. In 1997, a new migration law ended the five-year work contract programme and streamlined the process for ethnic return migrants to obtain citizenship. In practice, Mongolian Kazakhs still found it challenging to navigate the bureaucratic process necessary to obtain citizenship until the mid-2000s, when it became easier to obtain citizenship, but more challenging to receive the benefits that come with being included in the annual quota (Genina 2015, p. 97). Although many migrants stayed in Kazakhstan and became citizens after their work contracts ended, Karlygash and her husband were amongst those who returned to Mongolia. They returned when their five-year work contract expired, as originally planned, in order to be closer to their kin. Yet other Mongolian Kazakhs continued to migrate to Kazakhstan. By the mid-2000s, repatriates received a one-time stipend towards the costs of resettlement, rather than separate payments for transportation, housing, and livestock. This 'quota' payment was roughly US $\$ 850$ per person, and US $\$ 1,700$ for the household head, depending on which province migrants would join in Kazakhstan (Tusupbekova 2008). Registered ethnic migrants could receive additional services and benefits, including assistance finding employment, access to language courses and university scholarships, and temporary deferment from military draft (Beketaev 2009). To further encourage the rapid acquisition of citizenship, the 2007 law allowed new arrivals to receive quota benefits for three years after obtaining citizenship (Kuş̧̧u Bonnenfant 2012). According to a report issued by the United Nations High Commissioner for Refugees, approximately $88 \%$ of the repatriates who arrived between 1991 and 2011 have obtained Kazakhstani citizenship. ${ }^{15}$ In 2011, a new law on migration was passed, ensuring that repatriates can obtain citizenship and receive benefits if they enter the programme through the quota system. The law, however, requires each repatriate to certify that their ethnicity is Kazakh (Oka 2013).

Kazakh repatriates are not the only migrants in Kazakhstan. According to a World Bank study, Kazakhstan was ranked seventh amongst migrant-sending countries and ninth amongst migrant-receiving countries in 2003 (Mansoor \& Quillan 2006, p. 25). Cultural discrimination combined with ethnic repatriation programmes in Germany and Israel have led many Germans, Jews, and Slavs to leave Kazakhstan (Iglicka 1998; Pilkington 1998; Brown 2005; Peyrouse 2007; Hess 2016). At the same time, economic growth aided by the burgeoning oil and gas industry has attracted a large number of labourers from Uzbekistan, Kyrgyzstan and Tajikistan who enter Kazakhstan legally through the visa-free system. Only a small percentage of these migrants are university graduates formally hired for professional positions. The majority work informally in the construction, agriculture, and service sectors, send remittances back to families in their home countries, and do not desire to stay in Kazakhstan permanently. Given that their work is not regulated by the government, there is no consensus on the number of

\footnotetext{
${ }^{15}$ 'Special Report on the Situation Concerning the Rights of Oralmans, Stateless Persons and Refugees in the Republic of Kazakhstan', United Nations High Commission on Refugees Report (Astana, UNHCR Kazakhstan, 2012).
} 
labour migrants; official reports state that there are 40,000 documented foreign workers and approximately one million undocumented foreign workers in Kazakhstan, while unofficial estimates vary from 700,000 to two million (Laruelle 2013, pp. 88-90; Davé 2014, pp. 34647). Compared to these migrants, Kazakh repatriates have an unrivalled and 'privileged' status within Kazakhstan. In addition to being entitled to economic and social benefits, repatriates are the only migrant group that has a special route to citizenship, based on nationalist desires to increase the size of the Kazakh population. Over time, the economic benefits of obtaining citizenship in Kazakhstan have increased as Kazakhstan's economy has strengthened through oil and gas exploitation.

Our interviewees frequently noted that social welfare benefits for Kazakhstani citizens, including pensions, are more than twice that provided in Mongolia-although the cost of living is also significantly higher in Kazakhstan. Mongolian Kazakhs also perceive educational advantages with Kazakhstani citizenship, as citizens are eligible to compete for merit-based public university scholarships, and Kazakhstani diplomas are believed to offer greater opportunities than Mongolian diplomas. Marzhan, a middle-aged Mongolian Kazakh, regretted that her family did not migrate to Kazakhstan:

The education system is better in Kazakhstan compared to Mongolia. The government gives money to students, so they don't have to pay in order to study. In our country, it is more difficult to study because you have to pay for tuition and living expenses. Our system is also of lower quality. A person who completes a degree in Kazakhstan can get a good job, but if you graduate from a Mongolian university, you cannot get a good job. ${ }^{16}$

She also lamented that, once Mongolian Kazakhs move to Kazakhstan, Mongolian diplomas do not 'count' for much. As she explained, the government of Kazakhstan does not fully recognise Mongolian diplomas in job hiring practices, leading the children of many Mongolian Kazakhs to obtain their degrees in Kazakhstan.

Similarly, our Mongolian Kazakh interviewees believed that having a Kazakhstani passport offered more flexibility for travelling abroad. During one visit to the Mongolian countryside, we talked to Erzhan, an older Kazakh migrant who had returned to visit his relatives in Mongolia for a few weeks. Erzhan told us how he had driven by private car from northern Kazakhstan to Mongolia via Russia, and had no problems at either the Kazakhstan-Russian border or the Russia-Mongolian border. Erzhan found that his Kazakhstani passport allowed him to transit through Russia without a visa, but he would have needed special permission to transit through Russia if he was using a Mongolian passport. He also noted that having a Kazakhstani passport made it easier to travel to many other foreign countries, with the exception of China. ${ }^{17}$

Taken together, ethnic return migrants have been in a legally privileged status vis-à-vis nonKazakh immigrants as well as current Kazakhstani citizens, as a result of citizenship benefits and quota benefits respectively. The repatriation policy was designed under the assumption that repatriates will contribute to Kazakhstan's nation-building project through their knowledge of language and 'traditions' (Dobrota 2008).

\footnotetext{
${ }^{16}$ Interview with Marzhan, Deluun som, Bayan-Olgii aimaq, Mongolia, 16 July 2008.

${ }^{17}$ Interview with Erzhan, Bayannuur som, Bayan-Olgii aimaq, Mongolia, 5 July 2008.
} 


\section{Privileged exclusion and the political projects of (not) belonging}

At first glance, repatriated Kazakhs appear to be included in the political community: not only have they been recruited for their knowledge of Kazakh culture and language, but they have also been granted citizenship and special social welfare benefits. Yet these factors have not been sufficient to create a strong sense of belonging to the state: repatriated Kazakhs have been countered by opposing political processes and actions that foster exclusion and separation. Both state and non-state actors engage in political projects that maintain boundaries between 'insiders' (Kazakhs from Kazakhstan) and 'outsiders' (repatriated Kazakhs). These boundaries are mutually constituted. On the one hand, Kazakh ethnic return migrants often feel excluded from social and political life in Kazakhstan. On the other hand, they help reinforce this boundary by developing transnational identities and maintaining strong social networks with other Mongolian Kazakhs in both Kazakhstan and Mongolia.

One of the reasons that led to the Mongolian Kazakhs' failure to develop a strong sense of belonging to Kazakhstan relates to the politically controversial nature of the repatriation programme. As in other immigrant-receiving countries, local attitudes towards ethnic return migrants vary depending on a person's socioeconomic status, ethnic identity, and political outlook. In a study analysing debates about how the programme was received by Kazakhstani newspapers, Kuşçu (2014) finds both ideological and economic critiques. The ideological arguments are based on a preference for a civic national identity that emphasises a Kazakhstani identity rather than an ethnic-based, and hence Kazakh, national identity. The economic critiques highlight the cost of the repatriation programme, and it furthermore emphasises that the average repatriate does not make substantial contributions to Kazakhstan's national economy. These arguments first emerged in the early 1990s when existing citizens were struggling with the high inflation and unemployment that accompanied Kazakhstan's structural adjustment. The perceived inequalities have continued to generate resentment from middleclass Kazakhstani citizens of all ethnicities. In 2009, we met Aliya, a middle-aged Kazakh woman in Almaty, Kazakhstan, who fervently stated: 'I hate the oralman!'. ${ }^{18}$ At the time, she and her husband were building a new home on land they had purchased. It was taking a frustratingly long time to secure a high-interest loan (at approximately 20\%) and obtain the required approvals before building their dream house. Aliya was upset that the government gave repatriates the keys to brand-new houses with low-interest government loans (at 5-6\%), and could not understand why the government was putting repatriates ahead of other citizens. Aliya noted that Germany had also invited Soviet Germans to repatriate but, in her opinion, Germany did not do this at the expense of other German citizens. ${ }^{19}$

In addition, government policies that physically separate repatriates from other Kazakhstani citizens can set hurdles for the full integration of repatriated Kazakhs into Kazakhstani society. In the early 1990s, many repatriates were given housing that had been abandoned by Germans, Ukrainians and Russians who had left Kazakhstan to return to their lands of ethnic origin (Diener 2009, p. 228). In this sense, repatriates were not dispersed evenly across Kazakhstan: repatriates from the same sending country were in fact settled in clusters within towns and suburbs that once housed ethnic minority groups. Some repatriates eventually moved away from the locations where they were initially settled, but this policy contributed to an initial

\footnotetext{
${ }^{18}$ Interview with Aliya, Almaty, Kazakhstan, 26 June 2009.

${ }^{19}$ Several studies suggest that many Germans did actually resent the financial support that Germany provided to ‘integrate’ Soviet Germans (Mandel 2008, pp. 67-71; Hess 2016, pp. 7-9).
} 
feeling of separation. Similarly, the Nurly Kosh ('Enlightened Migration') initiative, launched in 2008 to steer repatriates away from the country's two largest cities (Almaty and Astana) and redistribute them to areas targeted for growth, also served to separate them from the broader community. The Nurly Kosh policy only applied to those repatriated Kazakhs who chose to enter through the quota system. Rather than settling them in deserted houses, local governments were tasked with building brand-new homes in special districts for repatriates. We visited a Nurly Kosh district near Shymkent in 2009. Although each home appeared to be comfortable and new, the neighbourhood's isolated location on the outskirts of the city prevented this group of repatriates from easily integrating and developing a sense of belonging to something larger than their own transnational community. As Aliya bitterly recounted, repatriates can get low-interest loans for these homes. However, her complaint does not take into account the fact that these homes tend to be located far from urban centres and migrants are required to stay in the house until the loan is entirely paid off. ${ }^{20}$

On an everyday level, the language used by Kazakhstani citizens also reinforces distinctions between 'insiders' and 'outsiders'. When the programme was first conceived, the concept of oralman was used for Kazakhs whose ancestors fled the present territory of Kazakhstan because of war, conflict, or collectivisation. Just as the terms 'gastarbeiter' and 'Aussiedler' reinforce the distance of Turkish migrants and Soviet-bloc Germans from 'native' Germans (Mandel 2008), the word 'oralman' establishes a boundary between 'native' and diasporic Kazakhs. Some Kazakhstani citizens see repatriates as opportunists who left the country during hard times, only to return for special treatment in the present (Dubuisson \& Genina 2011). As problems with integration have emerged, the term came to acquire a pejorative flavour. As a result of this connotation, some officials have questioned the continued use of the term, and proposed a more neutral alternative- 'yeldes' (compatriot). ${ }^{21}$

In colloquial speech, Kazakhstani Kazakhs refer to repatriates not as 'returnees' but in a way that conflates their birth country with their ethnicity. Diasporic Kazakhs from Mongolia are called 'Mongolians' and Chinese Kazakhs are referred to as 'Chinese'. Some Kazakhstani citizens even question the biological 'purity' and authenticity of repatriates who might have intermarried with other groups or be making false claims in order to qualify for benefits. Such attitudes were revealed when we showed photos from Mongolia to Kazakhstani friends living in the cities of Almaty and Shymkent. Several friends suggested that Mongolian Kazakhs looked like Mongolians with round faces and red cheeks. In addition to pointing out these physical differences, our Kazakhstani informants used these photos to make social distinctions between themselves and Mongolian Kazakhs, pointing out that the clothing worn by Mongolian Kazakhs seemed to be old-fashioned and their yurts and mud-block homes seemed to be in poor condition. After asking about the daily life and economic well-being of Mongolia's Kazakhs, one Kazakhstani Kazakh woman living in a rural village concluded the conversation by stating jubilantly: 'well, at least we live better than they do!'. ${ }^{22}$

These views differ from the way in which Mongolian Kazakhs describe themselves. When we were in Mongolia, local Kazakhs frequently referred to clear religious and cultural markers that distinguish themselves from Mongolians. They would point out that, as Muslims, they did

\footnotetext{
${ }^{20}$ Personal communication with Anna Genina, PhD candidate in anthropology, University of Michigan, 17 July 2009.

${ }_{211}$ 'Koshi-kon politiyasy elge oralgan kandastardy “oralman” dep atamaudy surady', Nur.kz Kazakhstansskii Portal, 25 September 2012, available at http://news.nur.kaz/232543_print.html, accessed 15 August 2016.

${ }^{22}$ Interview with Aizhan, Shymkent, Kazakhstan, 29 June 2009.
} 
a number of things differently, including the slaughter of their livestock (by slitting the throat of the animal, rather than cutting out its heart). They also pointed out material differences, such as their dress and the shape of their yurts. Although Kazakhstani Kazakhs question the biological purity of Mongolian Kazakhs (based on the perception that they share physical features with Mongolians), Mongolian Kazakhs take pride in the fact that their children do not marry Mongolians due to religious and cultural differences.

In addition to physical appearance and social distinctions, language skills further distinguish Mongolian Kazakhs from Kazakhstani Kazakhs. Mongolian Kazakhs may speak Kazakh and Mongolian well but they are unlikely to be proficient in Russian, the primary language of urban Kazakhstan (Diener 2005, pp. 471-72; Lacaze 2010, p. 197; Genina 2015). In the introductory vignette, elderly Anara wanted to return to Mongolia because of this linguistic challenge of assimilating to Kazakhstan. This issue affects Mongolian Kazakhs of all ages. For example, Gulsara, a Mongolian Kazakh woman in her mid-twenties, considered migrating from Mongolia to Kazakhstan to pursue new job opportunities. Many of her relatives live in Kazakhstan and regularly visit Mongolia to attend weddings and other events. Gulsara holds a degree from a Mongolian university, has strong English and work experience as an English teacher and a tour guide. Despite this background, she was concerned that she might not be able to find a professional job in Kazakhstan because her degree was from Mongolia and she did not speak Russian well. She knew that her aunt had been a nurse in Mongolia, but began working in a shop in Kazakhstan because her Mongolian credentials did not transfer. Similarly, Gulsara's uncle was an economics teacher in Mongolia, yet now owns a small grocery store in Kazakhstan. ${ }^{23}$ After we left, Gulsara shared via email that she had moved to Kazakhstan for several months, but ultimately returned to Mongolia and married a fellow Mongolian Kazakh. Finding a job and adapting to daily life was more difficult than she had expected, given the importance of Russian language proficiency in post-Soviet Kazakhstan. As she explained:

I thought it would be easier to live in Kazakhstan for people who know Kazakh, but it wasn't the same as I thought. Life's harder in Kazakhstan for those who don't know Russian, in the central areas. Everyone here speaks Russian ... and the Kazakhs speak differently from us, adding a lot of Russian. ${ }^{24}$

Although Gulsara self-identified as a Kazakh and felt a sense of belonging to Kazakhstan based on her ethnic identity, her difficulty in integrating and her reluctance to live there permanently suggested that she did not feel as if she fully belonged to Kazakhstan. Like many other Mongolian Kazakhs, Gulsara had developed a transnational identity that blended Kazakh ethnicity with Mongolian roots.

The extent to which these socially constructed boundaries between Mongolian Kazakhs and Kazakhstani Kazakhs affect a person varies from one person to the next. Some Mongolian Kazakhs experience other difficulties adapting to life in Kazakhstan. In numerous interviews, we were told that certain individuals 'did not adapt to the water and land' (Olar zher-su tarymaidy), and therefore chose to return to Mongolia. This phrase served as a code for health problems, and was most frequently used in reference to older individuals. For example, Sabirzhan, a 57-year-old male taxi driver, explained how he and his family lived in Kazakhstan

\footnotetext{
${ }^{23}$ Interview with Gulsara, Ulgii city, Mongolia, 6 June 2009.

${ }^{24}$ Email from Gulsara, 6 January 2010.
} 
for 14 years before returning to Mongolia. He used the expression above to talk about how he and his wife returned after becoming very ill: they believed the illness was due to differences in climate and the environment. ${ }^{25}$ Other migrants experienced culinary nostalgia for Mongolia, believing that meat and dairy products from livestock in Mongolia's Altai Mountains were superior to livestock products from the Steppes of Kazakhstan.

Not all Mongolian Kazakhs have as much difficulty adapting to Kazakhstan. Gulsara's aunt and uncle, for example, had found a way to adapt and, while their children were likely to integrate further into Kazakhstani society, Gulsara herself had problems adapting to the linguistic environment in Kazakhstan. Even those who stay often experience a sense of loss, which often surfaces in musical performances (Post 2007). Perhaps not unusually, Mongolian Kazakhs often cope with these losses by maintaining a transnational identity that links them simultaneously to both countries (Basch et al. 1994). Although they live in Kazakhstan, Mongolian Kazakhs maintain strong ties to Mongolia, as well as to other Mongolian Kazakhs living in Kazakhstan. For example, Anara and others who could afford the cost regularly travelled to visit kin in the other country. As mentioned above, Mongolian Kazakhs often live in clusters with other Mongolian Kazakhs in Kazakhstan, in both rural and urban settings. As a result of these strong ties, young members of this transnational community often marry each other, rather than Kazakhstani Kazakhs. Other times, as we experienced during our fieldwork, marriages are formed between young people who grew up in different countries. It is possible that the strength of these transnational ties may diminish in future generations, but these connections were still strong at the time of our research (2006-2009).

A big challenge for this transnational community is represented by restrictive legislation on dual citizenship. Some Mongolian Kazakhs circumvent this problem by illicitly maintaining dual citizenship (Alff 2013, p. 109). ${ }^{26}$ Short of taking this option, ethnic return migrants who acquire Kazakhstani citizenship expect difficulties if they try to regain Mongolian citizenship. We repeatedly heard that it could take five or more years to get Mongolian citizenship back and, as one interviewee explained: 'you need to submit a request [to the President of Mongolia]. It's very difficult to get Mongolian citizenship back. They can't leave Kazakhstan, because Kazakhstan doesn't want them to leave. It's very difficult' ${ }^{27}$ Another interviewee explained that returnees must first get a document from Kazakhstan renouncing citizenship there. People are reluctant to follow this path, because they know of stateless individuals who are temporarily ineligible to work or receive benefits in either country until they finalise their paperwork. Kazakhstan's policy of exclusive citizenship, along with the difficulties of regaining Mongolian citizenship, underscores that the ease of migration is unidirectional. As a result, ethnic return migrants who have not developed a strong sense of belonging to Kazakhstan may be socially excluded from Kazakhstan, and yet legally excluded from an easy return to Mongolia, unless they illegally maintain dual citizenship.

\footnotetext{
${ }^{25}$ Interview with Sabirzhan, Ulgii city, Bayan-Ulgii aimaq, 3 July 2006.

${ }^{26}$ As cited by Alff (2013, p. 109), in 2002 the unofficial estimate for the number of Mongolian Kazakhs with two passports (one legal, one illegal) was approximately 8,000 individuals.

${ }^{27}$ Interview with Aqylbek, Deluun som, Bayan-Ulgii aimaq, Mongolia, 22 July 2009.
} 


\section{Fewer benefits, increased exclusion}

Kazakhstan's repatriation programme has now been in existence for nearly 25 years. Throughout this period, the leaders of Kazakhstan balanced civic and ethnic models of the nation-state, and modified migration policy to balance nationalist desires while increasing the demographic proportion of Kazakh ethnics with the economic needs of the state. In this section, we demonstrate that the 'privileged' status of repatriates gradually weakened as Kazakhstan's migration policies have shifted to prioritise class, in addition to ethnicity.

From 2005 onwards, two trends have reduced the relative status of ethnic repatriates vis$\grave{a}$-vis other migrants. First, opportunities to migrate have increased for 'capital-bearing' and highly skilled workers of any ethnicity. Second, opportunities to migrate have declined for those ethnic return migrants with limited assets and skills. These trends have coincided with an important demographic development: according to the 2009 census, the Kazakh population had increased to a comfortable majority of the country's population at $63.1 \%$ (Oka 2013). Although it is beyond the scope of this article to duplicate existing coverage of all these shifts (Werner \& Barcus 2009; Mendikulova 2012; Oka 2013), we highlight here how the special status of ethnic return migrants has gradually eroded over the past two decades.

Although ethnic repatriates were the exclusive focus of Kazakhstan's initial migration policy, the government subsequently introduced policies that increased migration opportunities for non-Kazakhs, especially those with previous ties to Kazakhstan and those who benefit the economy. In 2007, for example, the government set a legal work quota for 55,000 nonKazakh migrants. Three of the four eligible categories represented professional workers (defined as executive personnel, highly qualified specialists, and skilled workers). The fourth category focused in turn on seasonal agricultural workers, who however constituted only a small portion of the new quota for non-Kazakhs (Laruelle 2013, pp. 100-1; Davé 2014, p. 351). The 2008 Nurly Kosh programme, while primarily intended for ethnic return migrants, included opportunities for a new category of return migrants: highly educated and skilled nonKazakhs who were former citizens of Kazakhstan (Oka 2013). On paper, at least, this meant that Slavs and Germans who had left Kazakhstan in the early 1990s could return to their birth country if they brought skills that could benefit the development of the new 'Eurasian' state. When President Nursultan A. Nazarbaev launched the Kazakhstan 2050 programme in 2012, he reiterated language about how the country seeks to 'attract the best foreign specialists in the open market and invite them to work in [Kazakhstan]' ${ }^{28}$ Collectively, these developments add class alongside ethnicity as a deciding factor for regulating entry into the country, thus marking an important shift in Kazakhstan's migration policies.

As new opportunities for non-Kazakhs began to emerge, legal benefits for ethnic return migrants started to decline. This development emerged as early as 2003, when Nazarbaev addressed the World Association of Kazakhs encouraging repatriation, yet warning that potential repatriates should not expect the government to solve all their problems. In a 2005 speech to the same organisation, the president channelled John F. Kennedy's inaugural address, avowing that a migrant 'should not think in terms of what Kazakhstan will give him but what he can give to his Kazakhstan' (Kuşçu Bonnenfant 2012, pp. 34-5). In 2008, this speech was followed by the introduction of the Nurly Kosh programme, which spelled out for the first

\footnotetext{
${ }^{28}$ See, 'President's Speech: Economic Pragmatism based on the Principles of Profitability, Return on Investment and Competitiveness', Kazakhstan Strategy 2050, available at: http://kazakhstan2050.com/ economic-policy/presidents-speech/, accessed 8 December 2017.
} 
time a preference for repatriates with higher education and skills. This preference was also listed in Article 20 of the 2011 Migration Law, the most recent law regulating migration to Kazakhstan. ${ }^{29}$

In practice, these changes in preference have slowed the flow of migrants from Mongolia. During our fieldwork in 2006-2009, we heard repeatedly that it had become more difficult for poor Kazakhs to migrate due to cutbacks in the benefits from the government and the increased cost of living in Kazakhstan. Our interviewees pointed out that it was harder to migrate now because the Kazakhstani government no longer provided free housing, and the cost of housing had become much more expensive. Nevertheless, we did encounter a number of people in Mongolia who were actively planning to migrate between 2006 and 2009. To facilitate their migration, these Kazakhs did however rely primarily on family networks, rather than on the Kazakhstani government. Some repatriates opt out of the quota system and rely entirely on family networks, as a way to live where they want to live, rather than in the state-designated areas (Genina 2015, pp. 97-8). Others rely on a combination of family networks and government assistance. For example, we met a herder named Zhibek in 2008, when his sister was visiting from Kazakhstan. At that time, he had little interest in moving, given the cost of migration and the challenges of assimilation..$^{30}$ One year later, we returned to his summer camp to discover that Zhibek and his wife had decided to migrate after they had lost one third of their livestock during a harsh winter freeze (dzhut). Zhibek was in the process of selling the remaining animals and preparing documents for his family to migrate. We listened as Zhibek and his friend calculated that it would cost approximately two million togrog (or just over US $\$ 1,000$ ) to resettle his family of six in Kazakhstan. Although he planned to apply for the quota benefits upon arrival, migration was feasible primarily because his sister and brother-in-law promised to provide Zhibek's family with a place to stay and financial support in Kazakhstan until he had a new job. They also promised to use their connections to help him find a job. ${ }^{31}$ These personal promises, not the government programme, gave Zhibek's family the sense of security that a future in Kazakhstan would be both possible, and more secure and predictable than life in Mongolia. Through these personal networks, individuals like Zhibek are able to develop a sense of belonging to the social community of Mongolian Kazakhs in Kazakhstan; however, this is not the same thing as having a sense of belonging to Kazakhstan as a nation-state.

In other geographical settings, the way migrants are perceived within the destination country is influenced by media coverage of the character of migrants, as well as their ability to integrate into the broader society. This is also true in Kazakhstan, where there has always been a mix of positive and negative stories about the repatriates. In general, Kazakhstan's Russian-language media have been more critical of the repatriation programme than the Kazakh-language media, which tend to have more of a nationalist bent. Positive portrayals of repatriates have consistently described the important contributions they are making to society, while emphasising their knowledge of Kazakh culture and language. In comparison, critical coverage of the repatriation movement has become increasingly negative over the years. Initially, such stories emphasised the high cost of the repatriation programme and

\footnotetext{
${ }^{29}$ Zakon Respubliki Kazakhstana, 2011, 'O migratsii naseleniya' Zakon Respubliki Kazakhstan ot 22 yulya 2011 goda No. 477-IV, available at: http://www.ilo.org/dyn/natlex/natlex4.detail?p_lang=en\&p_isn=90208\&p_ country=KAZ\&p_count=348, accessed 15 August 2016.

${ }^{30}$ Interview with Zhibek, Bayannuur som, Bayan-Ulgii aimaq, Mongolia, 7 July 2008.

${ }^{31}$ Interview with Zhibek, Bayannuur som, Bayan-Ulgii aimaq, Mongolia, 14 July 2009.
} 
questioned the ideological objectives of repatriation (Kuşçu 2014). More recent challenges to the programme have been based on new narratives that portray the repatriates as people involved with dishonourable and criminal activities. Negative media portrayals focus for example on illegal efforts to acquire extra quota payments or dual citizenship. To apply for repatriation, the head of household must (directly or via proxy) submit documents for all household members. Yet some individuals have attempted to register relatives who do not actually migrate, while others have produced fake documents (including fake Kazakhstani passports) to register a household, collect the quota money, and then return to Mongolia (Oka 2013). As Reeves (2013) points out in the case of Kyrgyz migrants in Moscow, migrants in post-Soviet spaces go to great effort to create credible fakes. Stories about repatriates cheating the system are frequently circulated in Kazakhstani newspapers (Dobrota 2008; Kupriyanova \& Raspopova 2012), including one case mentioning that, out of 2,000 individuals registered as oralman, only 400 actually crossed the border (Sheriyazdanova 2010).

In 2011, critical media coverage reached an all-time high when some state actors accused the oralman of playing a role in one of the most violent conflicts in post-Soviet Kazakhstan. This conflict started out as a peaceful labour dispute in Zhanaozen, a small town in oilrich Mangystau oblast'. Western Kazakhstan's oil boom had attracted both internal and international migrants, including repatriates from nearby Turkmenistan and Uzbekistan. In May 2011, thousands of oil workers went on strike for higher wages and better working conditions. When 2,000 striking employees were dismissed, demonstrations continued in the town's main square. On 16 December 2011 - the very day that the nation was celebrating its twentieth year of independence - violence broke out between police and civilians (Oka 2013). According to official accounts, 17 people were killed and dozens wounded. These events were framed as a major threat to national security and the political legitimacy of the president, and multiple narratives emerged about who had really instigated these events. The president established a special investigation, which led to the convenient arrests of several opposition leaders, including the human rights activist and journalist Vladimir Kozlov. While one thread of the local narratives focused on opposition leaders, another implicated the repatriates as 'outsiders' who had acted selfishly by protesting on Independence Day (Dzhaganova 2011). Several political and business leaders attributed the strikes to the large influx of repatriates into a region that lacked the infrastructure to support a population boom (Schenkkan 2012). In one official account, one of the president's advisers, Ermukhamed Ertysbayev, described the oralman as the main organisers of the strikes, noting that Kazakhstani Kazakhs do not typically protest against authorities (Beisinbinov 2012). His statement distinguished 'insider' Kazakhs from 'outsider' Kazakhs, while reinforcing the idea that the repatriates do not belong to the state in the way that other citizens do.

Then, four months after the events in Zhanaozen, the government announced that the repatriation programme had been suspended, without advance warning and without a clear timeframe for its resumption. ${ }^{32}$ This suspension did not mean that ethnic return migrants had to leave Kazakhstan, or that new ethnic return migrants could not acquire citizenship. It did mean, however, that unregistered repatriates could no longer apply for the quota benefits, and that registered oralman would not receive as much assistance (Oka 2013). These changes disproportionately affected poor repatriates.

\footnotetext{
${ }^{32}$ 'V Kazakhstane priostanovlena kvota na immigratsiyu oralmanov', Tengri News, 23 April 2012, available at http://tengrinews.kz, accessed 28 July 2012.
} 
The government's decision to suspend repatriation is best explained by shifting priorities, rather than financial limitations. In 2012, the government of Kazakhstan was in a much better financial position than when the repatriation programme was first introduced in the 1990s. An abundance of natural resources brought steady economic growth, which encouraged the migration of workers from other Central Asian countries, and the achievement of a Kazakh demographic majority in 2009 temporarily diminished concerns about the relative size of the Russian minority population (Oka 2013). While demographic changes weakened the need for the programme, increasingly negative portrayals of the repatriates helped justify the programme's suspension. The political situation changed two years later, after the RussianUkrainian conflict brought a new sense of urgency to the demographic situation in Kazakhstan. The repatriation programme was partially resumed in August 2013, and fully reinstated in 2014. The revived programme offers extra incentives for ethnic return migrants to settle in the northern territories along the Russian border where there are larger concentrations of Russians (Lillis 2014). ${ }^{33}$

As this section has demonstrated, Kazakhstan initially facilitated the naturalisation of ethnic return migrants, while maintaining discriminatory policies towards non-Kazakh groups. Yet as Kazakhstan resolved its demographic problems and increased its wealth, the government slowly started to open up opportunities for highly skilled workers to become citizens, regardless of ethnicity. The state also decreased benefit packages for new repatriates, suggesting a slightly reduced status for a social group that had once played an integral role in the nation-building process by helping to restore Kazakh demographic superiority. By allowing the state-managed media to highlight the perceived shortcomings of ethnic return migrants, the state modified its policy without diminishing the rhetorical importance of the nation-state as a national homeland for Kazakhs. Recent international events, however, have triggered a partial reversal of this situation, as evidenced by the reinstatement of the repatriation programme. All these changes demonstrate the ease with which citizenship logics and a sense of belonging can shift as new political circumstances emerge.

\section{Conclusion}

In today's world, millions of migrants cross international borders every year in search of economic opportunities or political sanctuary. All immigrant-receiving countries grapple with how to control and regulate migration. Policymakers balance moral, economic, and cultural considerations with decisions about which migrants are 'worthy' of work permits, refugee status and citizenship status. Additionally, segments of the population are often anxious about the impacts of migration on local communities, and express these fears by distinguishing outsiders as culturally and racially different. Social distinctions between citizens and immigrants are reinforced by policies that regulate who can enter the country and who can obtain citizenship. Citizenship and migration policies vary from one nation-state to the next, with some states giving preferences to migrants on the basis of socioeconomic status (education and occupation), and others setting priorities on the basis of ethnicity.

\footnotetext{
${ }^{33}$ 'Kazakhs Resume Helping Oralman', Central Asia Online, 29 August 2009, available at: http://centralasiaonline.com/en_GB/articles/caii/newsbriefs/2013/08/29/newsbrief-11, accessed 20 January 2015 .
} 
This article has focused on the case of post-Soviet Kazakhstan. Immediately after independence, Kazakhstan developed a migration policy that was liberal towards individuals who could show patrilineal Kazakh heritage, and restrictive towards other labour migrants (Laruelle 2013; Davé 2014). Kazakhstan's repatriation programme addressed ethno-national grievances in a post-Soviet context, including demographic concerns about the relative size of the Kazakh population. On average, repatriates came from relatively poor families who could not otherwise afford the cost of migration and resettlement. Although they have contributed to the economy, their primary contributions have been cultural and demographic. As Kazakhstan's economy expanded and ethnic Kazakhs established a comfortable majority, the government started to shift regulations to attract other migrants who could better benefit the state and temporarily suspended the programme for a few years, before reinstating the programme in the wake of Russia's annexation of Crimea.

This article is situated within a broad scholarly conversation about issues of citizenship and belonging amongst transnational populations (Kipnis 2004; Geschiere 2009; Yuval-Davis 2011). The case of Kazakhstan illustrates Yuval-Davis's argument that citizenship policies are just one of several 'political projects of belonging' that influence the extent to which migrant groups develop and maintain a sense of belonging to a new state. In Kazakhstan, many repatriates have failed to acquire a strong sense of belonging despite citizenship rights, social welfare benefits, and shared ethnicity. Using the concept of 'privileged exclusion', this article argued that the repatriates' citizenship advantages have not been enough to warrant a strong sense of belonging, given how other political actors have redefined boundaries between insiders and outsiders. Like other transnational migrants, ethnic return migrants feel emotionally and physically divided between close kin in two different countries. Yet, they are uniquely situated due to their ethnic ties to their destination country. Repatriated Kazakhs from Mongolia simultaneously belong because of their knowledge of Kazakh language and traditions, and yet do not belong because of their lack of fluency in Russian, the absence of a shared Soviet experience, and limited comfort with the 'cosmopolitan' lifestyle that characterises the new elite in this rapidly developing post-Soviet, Eurasian country.

This case study of Kazakhstan demonstrates the complexities of belonging experienced by transnational migrants in a post-Soviet setting that balances civic and ethnic modes of the nation. Citizens may experience multiple forms of belonging, including identification with the Kazakh nation (through shared ancestry), identification with the Kazakhstani nation (through shared experiences with the Soviet past), and identification with a Eurasian nation (and the connoted 'cosmopolitan' lifestyle). Belonging also entails the intersection of these identities with linguistic fluency, class, and gender. Additionally, an individual's sense of belonging might change over time in response to new discourses of belonging. Anara, for example, felt a strong attachment to Kazakhstan as her national 'homeland' yet, over time, she lost that feeling of attachment and belonging when Kazakhstani Kazakhs referred to her as a 'Mongol' and slighted her because she could not speak Russian.

Previous research illustrates how issues of belonging relate to other social groups in Kazakhstan. For example, Yessenova (2005) argued that Kazakhstani Kazakhs from Kazakhspeaking villages may feel that they belong culturally to the Kazakh nation, yet their economic or linguistic belonging in an increasingly stratified society may be limited as a result of their class background and limited linguistic fluency in Russian and English. Similarly, Peyrouse (2007) demonstrated that Kazakhstani Russians who can make autochthonous claims to 
Kazakhstani territory may feel belonging to a territory where their families have lived for generations, yet as Russians, they may not fully belong culturally or linguistically to the postSoviet Kazakh nation. Future research, then, is needed to explore how these different forms of belonging coexist in competing and shifting hierarchies to better understand how different groups (Kazakhstani Kazakhs, oralman, non-Kazakh citizens, non-Kazakh immigrants) simultaneously belong and do not belong given different axes of their personal identities in relation to the post-Soviet state.

Cynthia Ann Werner, Department of Anthropology, Mailstop 4352, Texas A\&M University, College Station, TX 77843-4352, USA. Email: werner@tamu.edu (iD) http://orcid.org/0000-0002-2662-8088

Celia Emmelhainz, Assistant Professor, Anthropology and Qualitative Research Librarian, 230 Kroeber Hall, University of California-Berkeley, Berkeley, CA 94720, USA. Email: emmelhainz@berkeley.edu (D) http://orcid.org/0000-0001-8853-8574

Holly BARCus, Professor and Chair, Department of Geography, Macalester College, St. Paul, MN, USA.Email: barcus@macalester.edu (D) http://orcid.org/0000-0002-3841-5725

\section{References}

Abazov, R. (2008) The Palgrave Concise Historical Atlas of Central Asia (New York, NY, Palgrave McMillan). Aksholakova, A. \& Ismailova, N. (2013) 'The Language Policy of Kazakhstan and the State Language in Government Service', Procedia-Social and Behavioral Sciences, 93.

Alff, H. (2013) 'Renegotiating Integration: Dual Citizenship and the Mobilisation of Social Networks among Mongolian Kazakhs', Inner Asia, 15, 1.

Anderson, B. (1983) Imagined Communities: Reflections on the Origin and Spread of Nationalism (New York, NY, Verso).

Barcus, H. \& Werner, C. (2010) 'The Kazakhs of Western Mongolia: Transnational Migration from 1990-2008', Asian Ethnicity, 11, 2.

Basch, L., Schiller, N. G. \& Blanc, C. S. (eds) (1994) Nations Unbound: Transnational Projects, Postcolonial Predicaments and Deterritorialized Nation-States (London, Gordon and Breach Science Publishers).

Beisinbinov, A. (2012) 'Kazakhstanskie Oral'many: Krakh operatsii “pereselenets”?', Fergana News, 24 May.

Beketaev, M. (2009) 'Klyuchevoe napravlenie migratsionnoi politiki', Kazakhstanskaya Pravda, 3 November.

Benhabib, S. \& Resnik, J. (eds) (2009) Migrations and Mobilities: Citizenship, Borders, and Gender (New York, NY, New York University Press).

Benson, L. \& Svanberg, I. (1998) China's Last Nomads: This History and Culture of China's Kazakhs (New York, NY, M.E. Sharpe).

Bosniak, L. (2006) The Citizen and the Alien: Dilemmas of Contemporary Membership (Princeton, NJ, Princeton University Press).

Boyle, P., Halfacree, K. \& Robinson, V. (2013) Exploring Contemporary Migration (New York, NY, Routledge).

Brown, A. J. (2005) 'The Germans of German and the Germans of Kazakhstan: A Eurasian Volk in the Twilight of Diaspora', Europe-Asia Studies, 57, 4.

Castor, F. (2013) 'Shifting Multicultural Citizenship: Trinidad Orisha Opens the Road', Cultural Anthropology, $28,3$.

Cerny, A. (2010) 'Going Where the Grass is Greener: China Kazakhs and the Oralman Immigration Policy in Kazakhstan', Pastoralism, 1, 1.

Ceuppens, B. \& Geschiere, P. (2005) 'Autochthony: Local or Global? New Modes in the Struggle over Citizenship and Belonging in Africa and Europe', Annual Review of Anthropology, 34.

Courtney, W. (2012) 'Kazakhstan's Democracy Gap', Open Democracy, June 2012, available at: http:// www.opendemocracy.net/od-russia/william-courtney/kazakhstans-democracy-gap, accessed 15 October 2013. 
Craith, M. N. (2004) 'Culture and Citizenship in Europe. Questions for Anthropologists', Social Anthropology, 12,3 .

Davé, B. (2004) 'Entitlement through Numbers: Nationality and Language Categories in the First Post-Soviet Census of Kazakhstan', Nations and Nationalism, 10, 4.

Davé, B. (2007) Kazakhstan: Ethnicity, Language and Power (New York, NY, Routledge).

Davé, B. (2014) 'Keeping Labour Mobility Informal: The Lack of Legality of Central Asian Migrants in Kazakhstan', Central Asian Survey, 33, 3.

Davenel, Y. (2012) 'Cultural Mobilization in Post-Soviet Kazakhstan: Views from the State and From NonTitular Nationalities Compared', Central Asian Survey, 31, 1.

Dzhaganova, A. (2011) 'Eto ne dolzhno povtoritsya', Kazakhstanskaya Pravda, 18 December.

Diener, A. (2005) 'Kazakhstan's Kin State Diaspora: Settlement Planning and the Oralman Dilemma', EuropeAsia Studies, 57, 2.

Diener, A. (2009) One Homeland or Two?: The Nationalization and Transnationalization of Mongolia's Kazakhs (Stanford, CA, Stanford University Press).

Dobrota, L. (2008) 'Vremen svyazuyushchii uzor', Kazakhstanskaya Pravda, 22 May.

Dubuisson, E. \& Genina, A. (2011) 'Claiming an Ancestral Homeland: Kazakh Pilgrimage and Migration in Inner Asia’, Central Asian Survey, 30, 3/4.

Esenova, S. (2002) 'Soviet Nationality, Identity, and Ethnicity in Central Asia: Historic Narratives and Kazakh Ethnic Identity', Journal of Muslim Minority Affairs, 22, 1.

Faranda, R. \& Nolle, D. B. (2011) 'Boundaries of Ethnic Identity in Central Asia: Titular and Russian Perceptions of Ethnic Commonalities in Kazakhstan and Kyrgyzstan', Ethnic and Racial Studies, 34, 4.

Fierman, W. (2005) 'Kazakh Language and Prospects for Its Role in Kazakh "Groupness", Ab Imperio: The Network of Empire and Nationalism Studies, 2.

Finke, P. (1999) 'The Kazakhs of Western Mongolia', in Svanberg, I. (ed.) Contemporary Kazaks: Cultural and Social Perspectives (London, Curzon Press).

Finke, P. (2003) 'Does Privatization Mean Commoditization?: Market Exchange, Barter, and Gift Giving in Post-Socialist Mongolia', in Dannhaeuser, N. \& Werner, C. (eds) Anthropological Perspectives on Economic Development and Integration (New York, NY, Elsevier).

Genina, A. (2015) Claiming Ancestral Homelands: Mongolian Kazakh Migration in Inner Asia, PhD Dissertation, Department of Anthropology, University of Michigan.

Geschiere, P. (2009) The Perils of Belonging: Autochthony, Citizenship, and Exclusion in Africa and Europe (Chicago, IL, University of Chicago Press).

Greenhouse, C. (ed.) (2011) The Paradox of Relevance: Ethnography and Citizenship in the United States (Philadelphia, PA, University of Pennsylvania Press).

Hess, C. (2016) 'Post-Perestroika Ethnic Migration from the Former Soviet Union: Challenges Twenty Years On', German Politics, 25, 3.

Hirsch, F. (2005) Empire of Nations: Ethnographic Knowledge and the Making of the Soviet Union (Ithaca, NY, Cornell University Press).

Holston, J. (2008) 'Insurgent Citizenship in an Era of Global Urban Peripheries', City and Society, 21, 2.

Humphrey, C. \& Sneath, D. (1999) The End of Nomadism? Society, State, and the Environment in Inner Asia (Durham, NC, Duke University Press).

Iglicka, K. (1998) 'Are They Fellow Countrymen or Not? The Migration of Ethnic Poles from Kazakhstan to Poland', International Migration Review, 32, 4.

Joppke, C. \& Rosenhek, Z. (2009) 'Contesting Ethnic Immigration: Germany and Israel Compared', in Tsuda, T. (ed.) Diasporic Homecomings: Ethnic Return Migration in Comparative Perspective (Stanford, CA, Stanford University Press).

Junisbai, A. (2010) 'Understanding Economic Justice Attitudes in Two Countries: Kazakhstan and Kyrgyzstan', Social Forces, 88, 4.

Kendirbaeva, G. (1999) "“We are the Children of Alash...” The Kazakh Intelligentsia at the Beginning of the 20th Century in Search of National Identity and Prospects of the Cultural Survival of the Kazakh People', Central Asian Survey, 18, 1.

Khazanov, A. (1994) Nomads and the Outside World (Madison, WI, University of Wisconsin Press).

Kipnis, A. (2004) 'Anthropology and the Theorisation of Citizenship', The Asia Pacific Journal of Anthropology, 5,3 .

Kolstø, P. (1998) 'Anticipating Demographic Superiority: Kazakh Thinking on Integration and Nation Building', Europe-Asia Studies, 50, 1.

Kupriyanova, A. \& Raspopova, S. (2012) 'Gosprogrammu pereseleniya oralmanov prevratili v kormushku', nur.kz, 16 July, available at: www.nur.kz, accessed 12 February 2013.

Kuşçu, I. (2008) Kazakhstan's Oralman Project: A Remedy for Ambiguous Identity?, PhD Dissertation, Department of Eurasian Studies, Indiana University. 
Kuşçu, I. (2014) 'Ethnic Return Migration and Public Debate: The Case of Kazakhstan', International Migration, 52, 2.

Kuşçu Bonnenfant, I. (2012) 'Constructing the Homeland: Kazakhstan's Discourse and Policies Surrounding its Ethnic Return-migration Policy', Central Asian Survey, 31, 1.

Kuzio, T. (2002) 'History, Memory and Nation Building in the Post-Soviet Colonial Space', Nationalities Papers, 30, 2.

Kymlicka, W. (1995) Multicultural Citizenship: A Liberal Theory of Minority Rights (Oxford, Clarendon Press).

Lacaze, G. (2010) "'Run after time": The Roads of Suitcase Traders', Asian Ethnicity, 11, 2.

Laruelle, M. (2013) 'Kazakhstan: Central Asia’s New Migration Crossroads', in Laruelle, M. (ed.) Migration and Social Upheaval as the Face of Globalization in Central Asia (Boston, MA, Brill).

Lillis, J. (2014) 'Kazakhstan: Astana Entices Kazakhs from Abroad amid Ukraine Crisis', eurasianet, 14 July, available at: http://www.eurasianet.org/node/69006, accessed 5 August 2014.

Lowe, L. (1996) Immigrant Acts: On Asian American Cultural Politics (Durham, NC, Duke University Press).

Luong, P. J. (2002) Institutional Change and Political Continuity in Post-Soviet Central Asia: Power, Perceptions, and Pacts (Cambridge, Cambridge University Press).

Lynch, M. \& Cox, N. (2007) 'Republic of Kazakhstan: Neglecting Refugees, Engendering Statelessness', Refugees International Bulletin, 20 December.

Mandel, R. (2008) Cosmopolitan Anxieties: Turkish Challenges to Citizenship and Belonging in Germany (Durham, NC, Duke University Press).

Mansoor, A. \& Quillin, B. (2006) Migration and Remittances: Eastern Europe and the Former Soviet Union (Washington, DC, World Bank Publications).

Marshall, T. H. (1983) 'Citizenship and Social Class', in Held, D. (ed.) States and Societies (New York, NY, Blackwell)

Martin, T. (2001) The Affirmative Action Empire: Nations and Nationalism in the Soviet Union, 1923-1939 (Ithaca, NY, Cornell University Press).

Mendikulova, G. (2012) 'Some Notes on Repatriation Politics in the Republic of Kazakhstan', Otan Tarikhy, 59,3 .

Miller, D. (2000) Citizenship and National Identity (London, Polity Press).

Nazpary, J. (2001) Post-Soviet Chaos: Violence and Dispossession in Kazakhstan (London, Pluto Press).

Ó Beacháin, D. \& Kevlihan, R. (2013) 'Threading a Needle: Kazakhstan Between Civic and Ethno-Nationalist State-Building', Nations and Nationalism, 19, 2.

Oka, N. (2013) 'A Note on Ethnic Return Migration Policy in Kazakhstan: Changing Priorities and a Growing Dilemma', Institute of Developing Economies, Discussion Paper No. 394, March.

Olcott, M. (1987) The Kazakhs (Stanford, CA, Hoover Institution Press).

Olcott, M. (2002) Kazakhstan: Unfulfilled Promise (Washington, DC, Carnegie Endowment for International Peace).

Ong, A. (1999) Flexible Citizenship: The Cultural Logics of Transnationality (Durham, NC, Duke University Press).

Ong, A. (2006) Neoliberalism as Exception: Mutations in Citizenship and Sovereignty (Durham, NC, Duke University Press).

Peyrouse, S. (2007) 'Nationhood and the Minority Question in Central Asia. The Russians in Kazakhstan', Europe-Asia Studies, 59, 3.

Pilkington, H. (1998) Migration, Displacement and Identity in Post-Soviet Russia (New York, NY, Routledge Press).

Pipko, S. \& Pucciarelli, A. J. (1985) ‘The Soviet Internal Passport System’, International Lawyer, 19, 3.

Portisch, A. (2012) “Like Unbroken Cream": Education and Livelihoods among the Kazakh of Western Mongolia', Anthropology and Education, 43, 4.

Post, J. C. (2007) "'I'll Take My Dombra and Sing to Remember My Homeland": Identity, Landscape and Music in Kazakh Communities of Western Mongolia', Ethnomusicology Forum, 16, 1.

Post, J. C. (2014) 'Performing Transition in Mongolia: Repatriation and Loss in the Music of Kazakh Mobile Pastoralists', Yearbook for Traditional Music, 46.

Reeves, M. (2013) 'Clean Fake: Authenticating Documents and Persons in Migrant Moscow', American Ethnologist, 40, 3 .

Reynolds, C. J. (2005) 'Nation and State in Histories of Nation-Building, with Special Reference to Thailand', in Gungwu, W. (ed.) Nation-Building: Five Southeast Asian Histories (Singapore, Institute of Southeast Asian Studies).

Ruget, V. \& Usmanalieva, B. (2008) 'Citizenship, Migration and Loyalty Towards the State: A Case Study of the Kyrgyzstani Migrants Working in Russia and Kazakhstan', Central Asian Survey, 27, 2.

Sassen, S. (1999) Guests and Aliens (New York, NY, The New Press).

Schatz, E. (2000) 'Framing Strategies and Non-Conflict in Multi-Ethnic Kazakhstan', Nationalism and Ethnic Politics, 6, 2. 
Schatz, E. (2004) Modern Clan Politics: The Power of 'Blood' in Kazakhstan and Beyond (Seattle, WA, University of Washington Press).

Schenkkan, N. (2012) 'Kazakhstan: Concern Rising over Ethnic Kazakh Returnees’, eurasianet, 29 February, available at: http://www.eurasianet.org, accessed 10 March 2012.

Sheriyazdanova, K. (2010) 'Vozvrashchenie. Adaptatsiya i obustroistvo', Kazakhstanskaya Pravda, 27 August.

Shugatai, A. (2012) 'Ethnic Immigration Policy Implementation (1992-2009)', Mongolian Journal of International Affairs, 17.

Slezkine, Y. (1996) 'N. la. Marr and the National Origins of Soviet Ethnogenetics', Slavic Review, 55, 4.

Spehr, S. \& Kassenova, N. (2012) 'Kazakhstan: Constructing Identity in a Post-Soviet Society’, Asian Ethnicity, $13,2$.

Suny, R. G. (2001) 'Constructing Primordialism: Old Histories for New Nations', The Journal of Modern History, 73, 4 .

Surucu, C. (2002) 'Modernity, Nationalism, Resistance: Identity Politics in Post-Soviet Kazakhstan', Central Asian Survey, 21, 4.

Svanberg, I. (1999) Contemporary Kazaks: Cultural and Social Perspectives (London, Curzon Press).

Thomas, D. A. \& Clarke, K. (2013) 'Globalization and Race: Structures of Inequality, New Sovereignties, and Citizenship in a Neoliberal Era', Annual Review of Anthropology, 42.

Tilly, C. (ed.) (1996) Citizenship, Identity, and Social History (Cambridge, Cambridge University Press).

Tsuda, T. (ed.) (2009) Diasporic Homecomings: Ethnic Return Migration in Comparative Perspective (Durham, NC, Duke University Press).

Tusupbekova, L. (2008) 'Migratsiya i ratsionalizatsiya', Kazakhstanskaya Pravda, 4 November.

Vora, N. (2013) Impossible Citizens: Dubai's Indian Diaspora (Durham, NC, Duke University Press).

Werner, C. \& Barcus, H. (2009) 'Mobility and Immobility in a Transnational Context: Changing Views of Migration among the Kazakh Diaspora in Mongolia', Migration Letters, 6, 1.

Werner, C. \& Barcus, H. (2015) 'The Unequal Burdens of Repatriation: A Gendered Analysis of the Transnational Migration of Mongolia's Kazakh Population', American Anthropologist, 117, 2.

Yessenova, S. (2005) “"Routes and Roots” of Kazakh Identity: Urban Migration in Postsocialist Kazakhstan', The Russian Review, 64, 4.

Yuval-Davis, N. (2011) The Politics of Belonging: Intersectional Contestations (London, Sage Publications).

Zeveleva, O. (2014) 'Political Aspects of Repatriation: Germany, Russia, Kazakhstan. A Comparative Analysis', Nationalities Papers, 42, 5. 